\title{
The Values of Pancasila in Electronic Banking Agreement
}

\author{
Andi Tenri Famauri \\ Faculty of Law, Hasanuddin University, Indonesia. E-mail: atenriariati@unhas.ac.id
}

\begin{tabular}{l} 
ARTICLE INFO \\
\hline Keywords: \\
Bank; Electronic Banking; \\
National Philosophy; \\
Pancasila \\
How to cite: \\
Famauri, A.T. (2019). The \\
Values of Pancasila in \\
Electronic Banking \\
Agreement, Hasanuddin \\
Law Review, 5 (3): 289- \\
298 \\
DOI: \\
10.20956/halrev.v5i3.2150 \\
\end{tabular}

\begin{abstract}
Pancasila as a state's foundation (philosophische grondslag), its values have exist, inherent and predicted in daily life as a way of life; therefore the material of Pancasila in the form of these values is the Indonesian Nation itself. The research is a normative-legal research. The research approach uses a statute, historical and conceptual approaches. The results show that Pancasila as the State's foundation (Philosophische Grondslag) is universal and open, especially in the life of nation; it can be used in all aspects of life. Changes in banking activities, from conventional to electronic banking (e-banking) cannot be avoided again. The elements of morality and good values in banking are much needed, because banks as financial institutions that manage public money as customers have a great responsibility must be accompanied by honesty and dedication as important elements in trust. Consider the foundation of business in the banking sector is trust. The principle of good faith is placed as super eminent principle in the agreement. It is based on the principle of good faith related with the behavior of someone that becomes a basis for the agreement to bind them (pacta sunt servanda). Thus, the basic values of Pancasila that emphasize fair and civilized humanity can be applied as part of the values that live in Indonesian peoples.
\end{abstract}

Copyright (C) 2019 HALREV. All rights reserved.

\section{Introduction}

Indonesia as part of a country in the world and develops without borders (borderless) must be involved in all global activities in all fields. The sector of banking is called electronic banking (e-banking) has been changed the paradigm of conventional banking become the interaction of parties in the cyberspace (virtual world). Pancasila as a State's foundation (Philosophische Grondslag), its values have existed since ago and have become an integral part of the identity of Indonesian people. These values already exist, inherent and predicted in daily life as a way of life; therefore the material of Pancasila in the form of these values is the Indonesian Nation itself. ${ }^{1}$ In addition,

\footnotetext{
1 Kaelan, M.S., Pendidikan Pancasila, 8th edition. Yogyakarta: Paradigma, 2004, p.28.
} 
Pancasila as an ethical system is a moral guidance that can be actualized into concrete actions involving various aspects of the life of the Indonesian nation.

Etymologically, the term of State foundation is identical to the terms of grundnorm (basic norms), rechtsidee (legal ideals), staatsidee (State ideals), philosophische grondslag (foundation of State philosophy). Many terms of State foundation in the vocabulary of foreign languages represents that the State foundation is universal, in the sense that every country has a State foundation. ${ }^{2}$ In terminology terms, a State foundation can be interpreted as a foundation and source in establishing and organizing the country. It can also be interpreted as the source of all sources of State law. Theoretically, the term of State foundation refers to the opinion of Hans Kelsen, is called a basic norm or Grundnorm.3

In essence, Pancasila is an identity of the Indonesian people because the values contained, born and developed in accordance with the soul of the nation, therefore to understand Pancasila comprehensively and intact especially related to national identity, it absolutely understand the history of the struggle of the Indonesian Nation, so that the values used from Pancasila in the form of philosophical values as a fundamental principle and State spirituality in a State institutions, where the state system of the Republic of Indonesia is formally a national institution that aims to realize the principles of normative-philosophical-ideological (in casu the State foundation of Pancasila state). ${ }^{4}$

As a nation, Indonesia has an inherent identity from the Indonesian nation before independence until now. The identity of Indonesian nation can be seen as a reflection to the character of the Indonesian nation. Pancasila values become a basis of the character of the Indonesian nation, as a noble value that has been developed in preindependence period. ${ }^{5}$

Pancasila as a State foundation is often also referred to as Philosophische Grondslag of the State, State ideology, staatsidee. In this case, Pancasila is used as a basis to organizing the State government or in other words, it is used as a basis for regulating the State administration. ${ }^{6}$ Human culture and civilization began and culminated in philosophical values that were developed and enforced as an ideological system or basis of a nation and State. It means the value of philosophy as a highest range of thought to find the ultimate truth. The truth is used in the practical field and gets illumination by that truth in life experiences. ${ }^{7}$

2 A lesson book for Mandatory Lecture Pendidikan Pancasila, Directorate General of Learning and Student of the Ministry of Research, Technologies and High Education of the Republic of Indonesia 2016, p. 80.

3 Hans Kelsen, Stuffen Bauf Theory, dikutip dari, Bachsan Mustofa, "Sistem Sosial Indonesia”, Bandung: Remaja Karya, 1987, p. 80.

4 Notonagoro, Beberapa Hal Mengenai Falsafah Pancasila, Jakarta: Pandjuran Tudjuh,1968, p. 53.

5 Gontar Alamsyah Siregar, et.al. Pengembangan Jati Diri Bangsa Melalui Peran PTNBH Di Indonesia (A Paper of MDGB-PTNBH, USU- Medan, 24-25 July 2019).

${ }_{6}$ Darmodiharjo, Moral Dan Etika. Jakarta: PT Gramedia Pustaka Utama, 1991, p. 86.

7 Muhammad Baqir Ash-Shadr, Falsafah Tuna, Terhadap Disertasi Pelbagai Aliran Filsafat Dunia, (Translated by: M. Nur Mufid bin Ali, Bandung: Mizan, 1995), p. 126. 


\section{Strengthening Pancasila Values as a State Philosophy}

Soekarno, the first President of Indonesia has been described shortly the urgency of Pancasila for the Indonesian people but convincing. Pancasila is Weltanschauung, a basic philosophy and means of unifying the nation which is also essentially a tool to unite in the struggle to eliminate all diseases that have been battled for decades, namely imperialism. The struggle of a nation is a struggle against imperialism, a struggle for independence, a struggle of a nation that carries its own style. There are no two nations have same way in struggle. Each nation has its own way of struggle and characteristics. Therefore, the nation as an individual has its own personality. Personality manifested in various things, in reality, economy, character, and so forth. ${ }^{8}$

In order to understand the urgency of Pancasila as a State foundation, we can use 2 (two) approaches, namely institutional and human resources. The institutional approach is to form and organize a State based on Pancasila values so that the Indonesian state fulfills the elements of a modern State, which guarantees the realization of the country's goals or the fulfillment of national interests, which lead to the realization of a just and prosperous society. Meanwhile, human resources lie in 2 (two) aspects, namely people who hold positions in government (State apparatus) who implement the values of Pancasila in a pure and consistent manner in fulfilling their duties and responsibilities so that the formulation of State policies will produce policies that embody the people's interests.

Currently, Indonesia in a period of transition, there is a traditional change to modern values, including changes in the legal system in several sectors, but keep in mind also between the law on the one hand with socio-cultural values on the other hand have a close relation, the close relationship between law and socio-cultural values indicates that a good law is a law that reflects the values that live in a society. ${ }^{9}$

For Indonesian nation, the values of Pancasila philosophy become a basis for developing the integrity of the Indonesian state. The philosophy of Pancasila as an ideology, as contained in the 1945 Constitution, it also reflects integrity as a system of Pancasila state with vision and mission as mandated in the 1945 constitution. ${ }^{10}$ In the hierarchy of Indonesian law source, Pancasila as a basic norm (groundnorms), it contained in the theory of State law by Hans Kelsen ${ }^{11}$ which means Pancasila is source of all sources of law, which animates all aspects of the life of the nation as outlined in the implementation of development. ${ }^{12}$

There are 2 (two) basic guidelines for the implementation of the values of Pancasila as moral norms of Pancasila for the State (nation) and the moral norms of Pancasila that needed for the implementation of Pancasila, because the implementation must be distinguished between two types i.e objective and subjective implementation. The objective is the implementation in all matters concerning the State administration and the life of the State which includes all the nature and State condition. While, the

\footnotetext{
8 Socialization material of Provisional People's Consultative Assembly in Period 2009-2014, Arrange by the Head of MPR dan Work Team 2013: 94-95).

${ }^{9}$ Lili Rasjidi and Ira Rasjidi, Dasar-Dasar Filsafat Dan Teori Hukum, Bandung: Cipta Aditya Bakti, 2007, pp. $80-81$.

10 Mohammad Noor Syam, "Filsafat Pancasila Sebagai Sistem Ideologi (Sebagai Sistem Kenegaraan Pancasila dan Pembudayaannya)", <http://lab.pancasila.um.ac.id/wp-content/uploads/filsafat-pancasila-mpr-ub2010.doc>.

11 Hans Kelsen, Stuffen Bauf Theory, as cited by Bachsan Mustofa, Op.Cit, p. 11.

12 Mochtar Kusumaatmadja, Konsep-Konsep Hukum Dalam Pembangunan, Bandung: Alumni, 2002, p. 3.
} 
subjective is an implementation concerns the private person, especially the State authorities, the leaders of the people and in society. ${ }^{13}$

National law based on the principle of Pancasila is used as a basis for Indonesian development; it is always structurally binding (government, law enforcers, and society), the legal substance created, ${ }^{14}$ and its implementation which is influenced by the culture or legal culture of the Indonesian nation. It is appropriate if related to the Theory of Development Law that dimensionally uses a frame of reference on the way of life and the Indonesian people based on the principle of Pancasila that is kinship system to the norms, principles, institutions and rules are already dimensions that include structure, culture and substance as stated by Lawrence W. Friedman. ${ }^{15}$

The legal basis of Pancasila as an open ideology is contained in the elucidation of the 1945 Constitution, that the constitution only contains the main rules and outlines as instructions to the central government and other organizers of the State to organize state life and social welfare. ${ }^{16}$ This is the latest development in conceptual thinking about the life of the community, nation and State, but also because of the right understanding of the implications of open ideology that is important in the task of responding to the development of society both nationally and internationally, in the present and future developing in a world that is currently developing without borders (borderless).

\section{Implementing Pancasila Values in Electronic Banking Agreement}

Since Pancasila has been accepted as the only principle of community, nation and State of the Indonesian, then ideologically the life of the nation has been established, it is expected to create prosperity in various aspects of national life. Pancasila which has been accepted to be the basic philosophy, it will become an ideology that animates the life of the nation in the field of socio-culture, social-economy, social defense-security.

In the life of economic, we know the term of Pancasila economy, which developed since 1980. In Pancasila economy, human beings are characterized by the belief in the one supreme God in addition to homo-economicus, as well as homo-metafisicus, and homomysticus, it meaning that in Pancasila economy, humans are not only seen from the aspect only, that is the instinct of economic, but as a perfect man. As perfect man both ways of thinking, behaving, and acting, they are not only based on economic stimulation, but also stimulated by social and moral factors. Social factor relates to other human beings and the communities, and moral factors relates to human as God's commandments with their creators. 17

13 Notonagoro, Op.Cit., p. 53

14 Bintan Siregar, Politik Hukum, Bandung: CV. Utomo, 2006, p. 1

15 Lilik Mulyadi, Teori Hukum Pembangunan Prof. Dr. Mochtar Kusumaatmadja, S.H., LL.M: Sebuah Kajian Deskriftif Analitis, hlm. 1. <ww.pn-pandeglang.go.id/attachments/125_kajian deskriptif analitis teori hukum pembangunan.pdf>.

16 Elucidation of 1945 Constitution post-amendment

17 Sariono Mangunpranoto, Dasar Filsafat Ekonomi Pancasila, dalam Mubyarto (eds), Ekonomi Pancasila, Yogyakarta: BPFE, 1981, p. 240. 
The Pancasila economic system is a market economic system that characterized by 5 (five) things, as follows: 18

1. The activity of national economic are driven by economic, social and moral stimuli;

2. There is a strong will of the citizens to realize social equality, they are not to allow the occurrence and development of economic and social inequalities;

3. The spirit of economic nationalism; in the era of globalization, it is clear the importance of the realization of a strong, resilient and independent national economy;

4. Economic democracy based on populist and kinship; cooperatives and cooperative efforts animating the economic behavior of individuals and communities; and

5. A harmonious, efficient and fair balance between national planning and economic decentralization and broad, free and responsible autonomy towards the realization of social justice for all Indonesian people.

Implementing the ideology of Pancasila, it can realize the principles of economic democracy including the banking industrial of Indonesia, which avoids the negative traits as expressed in the Broad Outlines of the Nation' Direction, namely a free fight liberalism system that fosters exploitation of people and other nations; etatism system in which the State and the economic apparatus is dominant and kills the potential and creation of private economic units; and concentration of the strength of the banking industry in one group that inflict a community. ${ }^{19}$

Banking as based on economic democracy, has a sense that the public must play an active role in banking activities, while the government (especially Bank of Indonesia), acts to provide direction and guidance to banking growth, while creating a healthy climate. In making policies and carrying out its business activities, it is obligatory to carry out their duties and authorities carefully, thoroughly and professionally to gain public trust.

A distinct description that the life and characteristics of banking institutions (as well as e-banking banking system although its shape and work procedure look modern, but still the value of the Pancasila philosophy contained in it) in Indonesia is more influenced by Pancasila ideology, and the goals of the State listed in the 1945 Constitution along with its amendments, it is a specific nature of the Indonesian banking institutions:20 the first; Indonesia banking in conducting their business are based on economic democracy using the principle of prudential. Its main function is as a collection and regulator of public funds, and it support the implementation of national development in the context of increasing equity, economic growth, and national stability towards the improvement of the people:21

The second; Indonesian banking as a means to maintain the sustainability of the implementation of national development, as well as to create a just and prosperous Indonesian society based on Pancasila and the 1945 Constitution, the implementation of Indonesian banking must pay much attention to harmony and balance of the development trilogy; and the third, Indonesia banking in carrying out their functions

18 Hermansyah, Hukum Perbankan Nasional Indonesia, Jakarta: Prenada Melia, 2005, pp. 18-19.

19 Malayu S.P. Hasibuan, Dasar-Dasar Perbankan, cet. ketujuh, Jakarta: Bumi Aksara, 2008. p. 4.

${ }^{20}$ Muhammad Djumhana, Asas-Asas Hukum Perbankan Indonesia, Bandung: Citra Aditya Bakti, 2008, p. 16

21 Provisions article 2, 3, and 4, Act No. 10 of 1998 on Banking. 
and responsibilities to the community must continue to move fast, in order to face increasingly severe and broad challenges, both in the development of national and international economies.

It has become a statutory provision as an agreement and State doctrine that Pancasila is a view of life, the ideology of the Indonesian nation which means that Pancasila as a view of life, awareness and moral ideals which encompasses the mental ambience and character of the Indonesian nation, ${ }^{22}$ also in the banking sector moral and ethical norms are needed other than legal norm. In addition, banks in conducting their business must always comply with all applicable laws and regulations in a manner that is based on good faith and honest transactions.

Good and honesty intentions, especially in e-banking agreement is an elaboration of the second principle of Pancasila "fair and civilized humanity" so that the Indonesian people automatically have a noble sense of humanity, which in essence humanity is human nature.

If something is considered as an act of humanity, it means that the action is in accordance with human nature, namely humanity, as such sense; all nations must have humanity (especially the Indonesian people who have Pancasila). The specificity of the Indonesian people is "fair and civilized", just means to give to others what is their right and know what their own rights are, civilized means to have moral, respectful, respect opinion, conviction of other parties or other nations. ${ }^{23}$

Theoretically, good faith is the basis for the law of agreement, that it is the principle of the promise from oneself to commit oneself (pacta sunt servanda). It is a standard customary law doctrine that in every contract there is an implied agreement of good faith and honest transactions. International institutional rules aimed at uniform trade rules govern good faith and honest transactions" each agreement imposes an obligation that is implementing good faith and honest transactions of performance or implementation. In an agreement an obligation is something that cannot be denied because the agreement of the parties, although they are free to determine what will be allowed or they need but on the basis of good intention. Good faith in performance is a way of expressing an obligation of loyalty or accuracy to the agreement of the parties.

(In the abstract, good faith is so basic to contract law that it amounts to the principle of promise-keeping itself: pacta sunt servanda. Accordingly, it is standar common law doctrine that "[i]n every contract there is an implied covenant of good faith and fair dealing." The Uniform Commercial Code provides that "[e]very contract...within this Act imposes an obligation of good faith in its performance or enforcement." And the implied covenant or obligation as such cannot be disclaimed by agreement of the parties, although they are free to determine by agreement what good faith will permit or require of them. Good faith in performance is a way of expressing an obligation of fidelity to the world of the contract and the parties' commitment to bring that world into being). ${ }^{24}$

The problem of freedom of choice between good and bad is very important in a number of contexts. This is not merely an academic question. All legal theories and practices regarding breach of contract are based on the assumption that the breach of

22 Ilhami Bisri, "Sistem Hukum Indonesia: Prinsip-Prinsip dan Implementasi Hukum di Indonesia", Jakarta: Raja Grafindo Persada, 2007, p. 7.

23 Sunoto, Op.Cit.,p. 3.

24 Burton, Steven J., and Andersen, Eric G., Contractual Good Faith: Formation, Performance, Breach, Enforcement, Canada: Little, Brown \& Company, 1995, p. 5. 
contract has "intentions" (motives) in their actions, and it can be found. The classic teaching on the responsibility of breach of contract states that this intention depends on the freedom of choice that has been made to act in this way. If the intention is not there (not found), except where there is negligence or carelessness, then there is no breach of contract. The accused must be able to do the opposite of what he/she has done. If not, he/she cannot be "responsible," he/she is not wrong and cannot be prosecuted. 25

Here, it can be explained, good faith and honest transactions made by someone from any party, whether bank or customer, have existed since the beginning of the contract, for example the fraud in the use of credit cards, which ended with a bad credit or a statement from a customer unable to pay their credit card bill, because it was originally intended to use a credit card as a means of debt, not as a means of payment as the original purpose of a credit card or also commonly referred to as paper money. In relation with these problems, Bank of Indonesia will tighten credit card issuance. It different with ignorance or lack of understanding of credit card user customers such as the calculation or due process of a credit card payment bill, resulting in a bad payment. If this happens, the bank will resolve the dispute that arises.

Basically, to resolve disputes arising in e-banking agreements is similar as conventional banking disputes resolved through mediation, this is for the Indonesian people who have Pancasila, always trying to avoid judicial institutions to resolve disputes, because one of the characteristics of the principles of democracy, namely in solving problems trying to go as far as possible through consultation to reach consensus. ${ }^{26}$

The problems that arise in rural areas may have to be dealt with more in traditional ways, in urban areas also not all problems can be solved without using traditional methods. ${ }^{27}$ This encourages the establishment of arbitration institutions which nonlitigation can be committed by Alternative Dispute Resolution either through consultation, mediation, negotiation, and affiliation, the Arbitration Law and APS can be done in the form of arbitration, negotiation, mediation, conciliation. ${ }^{28}$ Although, the available institutions may not meet the needs of the parties to the dispute, because many are influenced by a variety of inhibiting factors, such as the knowledge of the law influenced by political, economic, cultural, legal culture, and the parties' intentions also greatly affect the smooth proceedings in court and in court outside the court.

Efforts to resolve e-banking disputes that arise can be done through legal aspects by the existence of a set of rules and legal institutions that are authorized to resolve dispute, in addition it must prioritize moral values and norms and ethical relations in addition to the legal relationships that must be owned by each parties, because even in relationships that are virtual but must still prioritize business ethics, because the nature of existing relationships based on the humanities law that runs or the subject of this relationship is human. The law exists in human society, without society there is no law but on the contrary without law the community can still run. Although, it is also

25 John McLeish, Behaviour Sebagai Psikologi Perilaku Modern, terjemahan Latief Zachri, Bandung: Tarsito, 1986, p. 246.

26 Sunoto, Mengenal Filsafat Pancasila: Pendekatan Melalui Sejarah Dan Pelaksanaannya, Yogyakarta: Hanindita, cet. kelima, 1985. p. 104.

27 Soerjono Soekanto, Faktor-Faktor Yang Menpengaruhi Penegakan Hukum, Jakarta: Raja Grafindo Persada, 1983, p. 50.

28 The government has been enacted Act No. 30 of 1999 on Arbitration and Alternative Dispute Resolution. 
undeniable that the process and globalization tends to reduce social and cultural value (in which there is moral) in which it will coloring the purpose of law as ethical issues. ${ }^{29}$

In fact, Mochtar argues that the law has increasingly become culturally and socially neutral, in other words the law in the period of progress and modernization is increasingly becoming separated from human life as cultured-social human beings (depersonalized). ${ }^{30}$ In more implications, modernization (the newer term is globalization) is quietly weakens or even destroys traditional ways of life whose values were initially held in high esteem by the inclusion of western culture. ${ }^{31}$ But this situation, there was also strong resistance from groups who did not want the real change from the inclusion of Western culture, even though they might also support it, by reason that formal and law changes such as the application of modern laws and constitutions or political declarations can be achieved without experiencing difficulties or suffering. ${ }^{32}$ On other hand, the use of western cultural methods or the importation of any western material goods today is modernization to some extent modernization requires little or no change in the socio-political structure and personality traits of the nations that modernize.

A common kind of APS is mediation. It has grown and developed in line with the human desire to resolve disputes quickly, and satisfy both parties. Respect for the principle of good faith, and when the two ideas come into conflict; it is understandable that the latter should be given preference, as, for instance relating to the negotiation of contracts. ${ }^{33}$ Based on the good faith of both parties when a conflict arises, it puts forward negotiations, both only parties and assisted by third parties, through mediation.

The philosophy contained in mediation is that humans physically do not want themselves to be overwhelmed with conflicts and disputes over a long period of time. Human beings continue to search for patterns of dispute resolution, in order to fulfill their natural desire to live in peace, security, justice and prosperity. ${ }^{34}$

Thinking about violations or breach of conflict can occur because of an intentional, which is not using good faith and honest transactions or the terms in the contract (language) are not clear, giving rise to different perceptions from other parties. A good contract should clearly describe the needs of the contract, explaining what actions should be done or needed. On the other hand, the limitation of an action from a detailed explanation (standard contract) can be the reasons for a violation.

(This way of thinking about contract breach is most useful when a party enjoys discretion in the performance of a contract. A party enjoys discretion in the relevant sense when the express terms of the contract do not specify how a party is to behave in all circumstances. The parties may leave direction to one of them, intentionally or by the use of unclear language, on the matters. Contracts allowing direction illustrate vividly how the world of the contract need to contain fully specified description of required action. Rather, it may

${ }_{29}$ Mochtar Kusumaadmadja dan B. Arief Sidharta, Pengantar Ilmu: Suatu Pengenalan Pertama Ruang Lingkup Berlakunya ilmu Hukum, Bandung: Hukum, Alumni, 2009, p. 53.

30 Ibid

31 Fred W. Riggs dikutip dari buku Beling \& Totten (Eds), Developing Nation: Quest For A Model, Disunting Oleh Bur Rasuanto, Modernisasi Masalah Model Pembangunan, Jakarta: Rajawali, 1980, pp.28-29.

32 Ibid

33 Crepeau, A. Paul., dan Charpentier, M. Elise., The UNIDROIT Principles and Civil Code of Quebec: Shared Value?, Canada: Carswell, Thomson Professional Publishing, 1998, pp.47-59.

34 Syahrizal Abbas, Mediasi dalam Persektif Hukum Syariah, Hukum Adat, dan Hukum Nasional, Jakarta: Kencana Media Group, 2009, p. ix. 
contain a restricted set of possible actions for allowed reasons, and a use of direction for those reasons would be a breach of contract). 35

Moral life or morality is a fundamental requirement in upholding Pancasila for the State, nation, and society, because Pancasila does not only collect legal norms, but most collects moral norms. ${ }^{36}$ Conversely, moral values and norms do not stand alone, but always accompany other norms and values, such as norms and aesthetic, social, cultural and legal norms and values. ${ }^{37}$

The relationship of moral norms with the field of law are inseparable, law without morality is tyranny as well as moral without law is anarchy and utopia that leads to bestiality. Moral norms, especially moral norms contained in the values of Pancasila are in line with the morals needed in business ethics, especially in banking relations, including the resolution of disputes that may arise.

Relationship of e-banking agreements, including dispute resolution which if arises, good faith and honest transactions are needed, it is related with moral norms. In this relationship, more than one party is formed, so in addition to normative legal rules, norm values are also required, which bind each party, on the one side, Bank of Indonesia as the central bank in Indonesia and independent bank supervisors. This independent bank supervisory institution is regulated in Article 34 of Act No. 23 of 1999 which has been amended by Act No. 3 of 2004, although it was said that this institution was independent, it said that the institution was still regulated by Bank of Indonesia in implementing its supervision. The other party in e-banking agreement is the customer, who must also prioritize the moral values of good faith and honest transactions.

Assessment of humans as contained in the Pancasila, people can only pay attention to the words, actions, and behavior of human temperament. Humans who do not match their beautiful words with their actions and behavior are called hypocrites, while in the field of law can be categorized as breach of contract actions, this is very dangerous for the community, nation, and State includes to resolve e-banking agreement disputes, there must be harmony between words, actions that have been preceded by the signing of an agreement to resolve disputes.

Pancasila as an ethical system is a moral guidance that can be actualized into concrete actions involving various aspects of life. Therefore, the principles of Pancasila need to be actualized further into action decisions so that they are able to reflect a variety of positive attitudes, such as: honesty that always puts good faith, discipline, responsibility, and independence. ${ }^{38}$

\section{Conclusion}

Pancasila as the State's foundation (Philosophische Grondslag) is universal and open, especially in the life of nation; it can be used in all aspects of life. Changes in banking activities, from conventional to electronic banking (e-banking) cannot be avoided again. The elements of morality and good values in banking are much needed, because banks as financial institutions that manage public money as customers have a great

\footnotetext{
35 Idem., P. 4

36 Hazairin, Demokrasi Pancasila, Jakarta: Bina Aksara, 1981, P. 95.

37 Sinuor Yosephus, L., Etika Bisnis, Jakarta: Pustaka Obor Indonesia, 2010, P. 223.

38 A lesson book of Mandatory Lecture Pendidikan Pancasila, $1^{\text {st }}$ edition , Op.Cit,. 7
} 
responsibility must be accompanied by honesty and dedication as important elements in trust. Consider the foundation of business in the banking sector is trust. The principle of good faith is placed as super eminent principle in the agreement. It is based on the principle of good faith related with the behavior of someone that becomes a basis for the agreement to bind them (pacta sunt servanda). Thus, the basic values of Pancasila that emphasize fair and civilized humanity can be applied as part of the values that live in Indonesian peoples.

\section{Conflict of Interest Statement:}

The author(s) declares that the research was conducted in the absence of any commercial or financial relationships that could be construed as a potential conflict of interest.

Copyright $\odot 2019$ HALREV. All rights reserved. 